\title{
Rheophytic Adaptation of Eurya japonica Thunb. (Ternstroemiaceae)
}

\author{
Masayuki Shiba ${ }^{1}$, Tomoki Tate ${ }^{2} \&$ Tatsuya Fukuda ${ }^{1}$ \\ ${ }^{1}$ Graduate School of Integrative Science and Engineering, Tokyo City University, Tokyo, Japan \\ ${ }^{2}$ Graduate School of Integrated Arts and Sciences, Kochi University, Nankoku, Kochi, Japan \\ Correspondence: Masayuki Shiba, Graduate School of Integrative Science and Engineering, Tokyo City University, \\ Japan
}

Received: October 13, 2021

Accepted: November 13, 2021

Online Published: November 25, 2021

doi:10.5539/ijb.v13n2p65

URL: https://doi.org/10.5539/ijb.v13n2p65

\begin{abstract}
Plants along rivers have narrow leaves to avoid the stress caused by the river's flow during flooding. Plants that have undergone such morphological leaf modifications to adapt to rivers are called rheophytes. Some populations of Eurya japonica Thunb. (Ternstroemiaceae) were grown on riversides so that the comparative morphology and anatomy of leaves between riverside and inland (control) populations could be examined to confirm their rheophytic speciation. Our morphological and anatomical analyses revealed that the leaf of E. japonica in the riverside populations was significantly smaller than that of the inland populations due to the decreased number of cells; therefore, the pattern of rheophytic differentiation in riversides was not the stenophyllization but the miniaturization of the leaf. Moreover, our results indicated that this species in the riverside populations had thicker leaves and higher density of stomata than those of inland populations, suggesting that E. japonica had been morphologically modified in response to the light and water environments along the river.
\end{abstract}

Keywords: adaptation, Eurya japonica, leaf, morphology, rheophyte

\section{Introduction}

Diverse environments have led to plants evolving various traits to adapt to them, such as the dwarf plants in the alpines and the succulent leaves in the drylands. Among them, riverside environments have been selected for plants with narrow lanceolate or cuneate leaves, called rheophytes, to adapt to sudden flooding and strong river currents after heavy rain (van Steenis, 1981). Therefore, artificial alternations, such as dams, to avoid flooding of rivers could affect the vegetation along the riverside because the selective pressure changes in the area downstream (Saito, Hoshino, Yoshikawa, \& Hoshino, 2019); in fact, Azami, Saitou, Kodama and Watanabe (2001) reported that the change in communities along riversides from Phragmites japonicus Steud. (Poaceae) to Lolium arundinaceum (Schreb.) Darbysh. (Poaceae), Pueraria lobata (Willd.) Ohwi (Fabaceae) and Rosa multiflora Thunb. (Rosaceae) was observed downstream of the Miharu Dam on the Ohtakine River in Fukushima Prefecture.

Similar adaptive modifications of leaves in rheophytes have occurred independently in various plant families (van Steenis, 1981). In fact, some comparative studies using rheophytic and closely related species have been conducted as model cases of leaf modification. To elucidate the formation of these leaves, for example, a comparative anatomical study of fern rheophytes, Osmunda lancea Thunb. (Osmundaceae) and its closely related dryland species, O. japonica Thunb. indicated a strong correlation between the gross morphology and anatomy of leaves (Imaichi \& Kato, 1992). In angiosperms, Usukura, Imaichi and Kato (1994) concluded that the narrow leaves of the rheophyte Farfugium japonicum (L. fil.) Kitam. var. luchuense (Masam.) Kitam. (Asteraceae) evolved because of the decreased number of leaf cells across the width of the leaf. Moreover, the rheophytic species of Rhododendron indicum f. otakumi and R. ripense Makino (Ericaceae) were involved only in the decreased number of leaf cells (Setoguchi \& Kajimura, 2004; Ueda et al., 2012), and the narrow leaves of Viola mandshurica W. Becker var. ikedaeana (W. Becker ex Taken.) F. Maek. (Violaceae) were also induced by a decrease in number of cells (Matsui et al., 2013). Although their narrow lanceolate or cuneate leaves were formed by changes in the number of leaf cells, Tsukaya (2002a) and Yamada et al. (2011) reported a variation in leaf width in the rheophyte Dendranthema yoshinaganthum (Makino ex Kitam.) Kitam. and Aster microcephalus (Miq.) Franch. et Sav. var. ripensis Makino in Asteraceae were involved in both the size and number of leaf cells. In addition, Ohga et al. (2012) indicated that the rheophytic ecotype of Adenophora triphylla (Thunb.) A.DC. var. japonica (Regel) H. Hara (Campanulaceae) has also been involved in both, the size and number of leaf cells. In this way, it has been clarified that the formation process of narrow leaves in rheophytes was categorized into the following two patterns: one was 
formed by only decreasing the number of cells, and the other was involved in decreasing not only the number but also the size of leaf cells.

In addition to cell size and number of leaves, some anatomical studies reported that rheophytic species had seen an increase in their stomatal size density, suggesting that they had differentiated the use of solar radiation and water for photosynthesis from closely related inland species (Ohga et al., 2012; Ueda et al., 2012; Matsui et al., 2013). These observed morphological and anatomical traits of rheophytic species could be explained by certain aspects of the riparian environment, such as high irradiation and frequent flooding after heavy rainfall-to which they were exposed. Above mentioned studies of rheophytic differentiation have clarified these traits by comparison with the putative rheophyte and its closely related inland species or ecotypes. However, in the case where the species growing in a mountainous area invade the riversides or when it grows continuously from a mountain to a riverside, it is doubtful whether the plant possessed the above-mentioned morphologies.

Eurya japonica Thunb. (Ternstroemiaceae) is approx. 1-3.5 m tall, has broad-leaved, evergreen woody perennials, and is widely distributed in Japan from Honshu to Ryukyu and Taiwan, southern China and Korea, and inhabits forests dominated by Pinus spp and Quercus spp. in Japan. This species has been found in various riparian forests in Japan (Yamaguchi, 2004; Shimada \& Tani, 2005; Ito et al., 2008; Fujimaki et al., 2015), and our preliminary survey confirmed that E. japonica also grew in areas that sustain flash floods along the following rivers in southern Shikoku: Shimanto, Yusuhara, Yoshino, Naka, Ioki, and Asemi rivers (Figure 1). Moreover, it is interesting that E. japonica grew sympatrically with the rheophytic $R$. ripense at all points along the riversides mentioned above in our preliminary survey. In addition to the rheophytic $R$. ripense, we confirmed that $E$. japonica was sympatric with $D$. yoshinaganthum at the survey site of the Naka River, the rheophytic ecotype of Ad. triphylla var. japonica in the Shimanto and Yoshino rivers, $V$. mandshurica var. ikedaeana in the Asemi River and As. microcephalus var. ripensis in the Ioki and Yusuhara Rivers. Therefore, it was very interesting that E. japonica on these riversides may have experienced the rheophyteic modification because it grew together with the above mentioned rheophytes under selective pressure of sudden flooding and strong river flow after heavy rain, but no research has been conducted so far focusing on such morphological and anatomical differences found in between varying environments. A comparison of these riverside E. japonica populations with their inland populations could reveal some differentiation for this species to adapt to riversides. Therefore, we conducted comparative morphological and anatomical analyses to investigate the differentiation between them.

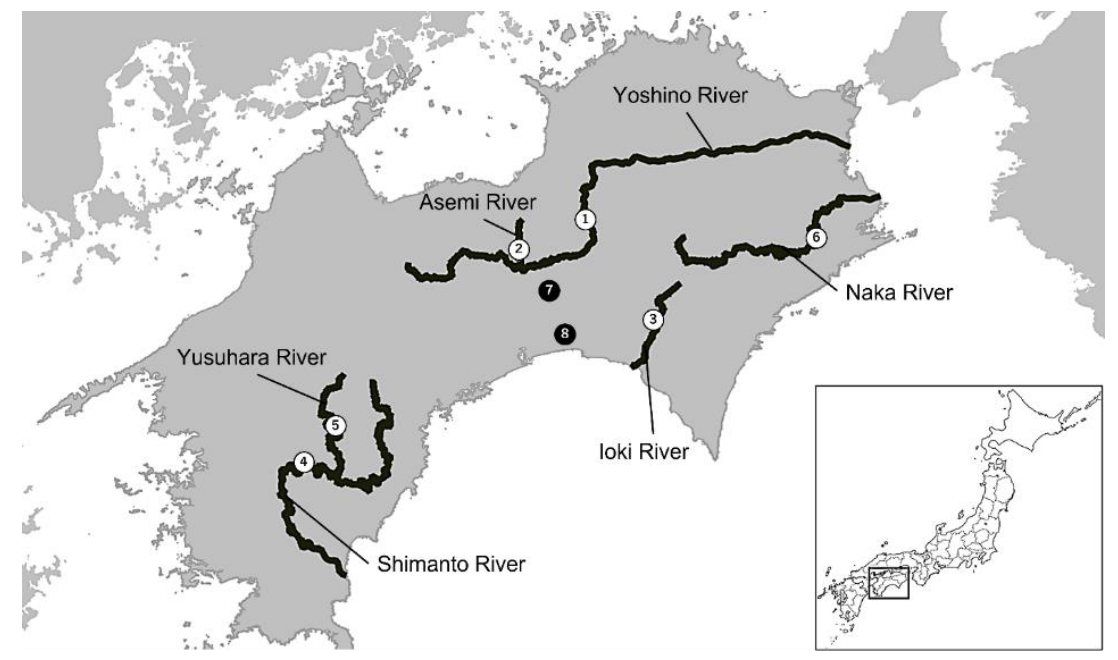

Figure 1. Sampling localities in this study. White and black circles indicate riverside and inland (control) populations, respectively. Number in circles corresponds to that given in Table 1

Table 1. Sampling localities used in this study

\begin{tabular}{|c|c|c|c|c|c|}
\hline Type & \multicolumn{2}{|l|}{ Locality name (River) \& number* } & Locality & \multicolumn{2}{|c|}{ Latitude and longitude } \\
\hline \multicolumn{6}{|c|}{ riverside } \\
\hline & Oboke (Yoshino River) & 1 & Kamimyo, Yamashiro-cho, Miyoshi City, Tokushima Pref. & $33^{\circ} 53^{\prime} \mathrm{N}$ & $133^{\circ} 46^{\prime} \mathrm{E}$ \\
\hline & Motoyama (Asemi River) & 2 & Sougauchi, Motoyama-cho, Nagaoka-gun, Kochi Pref. & $33^{\circ} 47^{\prime} \mathrm{N}$ & $133^{\circ} 33^{\prime} \mathrm{E}$ \\
\hline & Koi (Ioki River) & 3 & Koi, Aki City, Kochi Pref. & $33^{\circ} 37^{\prime} \mathrm{N}$ & $133^{\circ} 59^{\prime} \mathrm{E}$ \\
\hline & Tokawa (Shimanto River) & 4 & Tokawa, Shimanto-cho, Takaoka-gun, Kochi Pref. & $33^{\circ} 14^{\prime} \mathrm{N}$ & $132^{\circ} 52^{\prime} \mathrm{E}$ \\
\hline
\end{tabular}




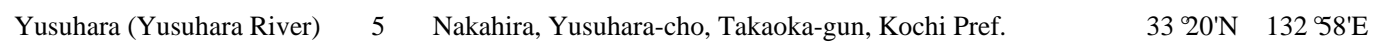

$$
\begin{aligned}
& \begin{array}{llll}
\text { Naka (Naka River) } & 6 & \text { Momae, Naka-cho, Naka-gun, Tokushima Pref. } & 33^{\circ} 50^{\prime} \mathrm{N} \quad 134^{\circ} 30^{\prime} \mathrm{E}
\end{array}
\end{aligned}
$$

Inland (control)

$$
\begin{aligned}
& \text { Shigeto } \\
& 7 \text { Kashinotani, Tosayamada-cho, Kami City, Kochi Pref. } \\
& 33^{\circ} 41^{\prime} \mathrm{N} \quad 133^{\circ} 39^{\prime} \mathrm{E} \\
& \text { Noichi }
\end{aligned}
$$

*: locarity no. corresponds to that given in Figure 1.

\section{Method}

All samples of Eurya japonica examined in this study were collected from the field. We collected samples from eight localities (six localities on the riversides and two in the inland). These localities were named as follows: six riverside areas including (Oboke [Yoshino River], Motoyama [Asemi River], Koi [Ioki River], Tokawa [Shimanto River], Yusuhara [Yusuhara River], and Naka [Naka River]), and two inland areas (Shigeto [Experimental Forest in Kochi University], and Noichi [Mt. Sanpo]). Localities are indicated in Figure 1 and Table 1. E. japonica was analyzed in a total of 210 individuals on the riversides ( 40 from Oboke, 30 from Motoyama, 38 from Koi, 31 from Tokawa, 30 from Yusuhara, and 41 from Naka) and 63 individuals (33 from Shigeto30 and from Noichi) from the inland areas.

For morphological analysis, individuals were measured for the following continuous macromorphological variables of leaves: length and width of the leaf blade, and angle of the leaf base were measured with a digital caliper and a protractor. Fully expanded leaves were analyzed. Five leaves were randomly measured from one individual, and their values averaged of them was used as the value of that individual.

For anatomical analysis, fully expanded leaves were collected from each individual. The leaves were fixed in a solution of formaldehyde, ethanol, and acetic acid (FAA) overnight. To count the number of cells on the blade, the surface of the fixed leaves was peeled off using Suzuki's Universal Micro-Printing (SUMP) method (Kijima, 1962). The middle part of the blade along the midrib was analyzed to determine the number and size of the epidermal cells. Replicas of each leaf $\left(1 \mathrm{~mm}^{2}\right)$ were used to measure stomatal density. These copied SUMP images were examined twice for each leaf under a light microscope.

To measure the thicknesses of the epidermal cell, palisade tissue, and spongy tissue, the fixed leaves were dehydrated by immersion in a graded ethanol series and then embedded in paraffin. Cross-sections of leaves were $8 \mu \mathrm{m}$ thick. The widest part of the blade was analyzed to determine the size of the palisade cells. The samples were also examined under a light microscope.

\section{Results}

In the Results section, summarize the collected data and the analysis performed on those data relevant to the discourse that is to follow. Report the data in sufficient detail to justify your conclusions. Mention all relevant results, including those that run counter to expectation; be sure to include small effect sizes (or statistically nonsignificant findings) when theory predicts large (or statistically significant) ones. Do not hide uncomfortable results by omission. Do not include individual scores or raw data with the exception, for example, of single-case designs or illustrative examples. In the spirit of data sharing (encouraged by APA and other professional associations and sometimes required by funding agencies), raw data, including study characteristics and individual effect sizes used in a meta -analysis, can be made available on supplemental online archives.

We analyzed the leaf morphology of Eurya japonica using morphological and anatomical approaches. A summary of the measurements of leaf morphology is presented in Table 2. We calculated the mean leaf length, width, thickness, and angle of the leaf base for each individual. Leaf length and width in the riverside populations were smaller than those in the inland populations. To detect stenophyllization, which means the process of narrow leaves, in riverside populations, leaf index values were calculated as the ratio of leaf length to leaf width based on Tsukaya (2002b). If the results of comparing these leaf index values between riverside and inland populations show a significant difference, this indicates that the population with the large value has narrow leaves. No significant difference between the riverside and inland populations was detected in the leaf index. Moreover, there was no significant difference in the angle of the leaf base between them, indicating that these populations have similar leaf silhouettes, although the leaf in the riverside populations was significantly smaller than that of the inland plants.

We calculated the mean epidermal cell size using the length and width of the cell measured from the SUMP samples of this species (Table 3). The results showed that the cell length, cell width, and cell size were not significantly different between the riverside and inland populations. These results of epidermal cells of leaves indicated that the difference in leaf size between riverside and inland populations was caused not by the difference in cell size, but by the difference in the 
number of cells. In addition, the results of measuring the tall of epidermal cells, palisade tissue, and spongy tissue, which contributes to the thickness of the leaves using longitudinal sections of leaves, are shown in Table 4. The results showed that the thickness of epidermal cells on both sides was significantly different between riverside and inland populations, but palisade and spongy tissues showed no clear differences between them. In palisade tissue, samples from Koi (Ioki River) had similar thicknesses to those of inland populations, but samples from other riversides were significantly thicker than those from inland populations. For spongy tissue, however, samples from Oboke (Yoshino River) and Tokawa (Shimanto River) were thicker than those from the inland areas.

Table 2. Leaf morphology (average \pm standard error) of Eurya japonica

\begin{tabular}{|c|c|c|c|c|c|c|c|c|}
\hline & \multicolumn{6}{|c|}{ Riverside } & \multicolumn{2}{|c|}{ Inland (control) } \\
\hline & Oboke & Motoyama & Koi & Tokawa & Yusuhara & Naka & Shigeto & Noichi \\
\hline length (mm) & $31.92 \pm 0.78^{\mathrm{d}}$ & $42.02 \pm 0.95^{\mathrm{bc}}$ & $46.47 \pm 1.23^{\mathrm{b}}$ & $38.16 \pm 0.88^{c}$ & $40.63 \pm 0.83^{\mathrm{c}}$ & $33.36 \pm 1.02^{\mathrm{d}}$ & $55.00 \pm 0.90^{\mathrm{a}}$ & $54.01 \pm 1.13^{\mathrm{a}}$ \\
\hline width (mm) & $12.24 \pm 0.32^{\mathrm{f}}$ & $16.28 \pm 0.28^{c}$ & $15.92 \pm 0.30^{\mathrm{cd}}$ & $13.89 \pm 0.34^{\mathrm{e}}$ & $14.69 \pm 0.24^{\mathrm{d}^{\mathrm{e}}}$ & $13.42 \pm 0.31 \mathrm{e}^{\mathrm{e}}$ & $20.84 \pm 0.33^{b}$ & $22.92 \pm 0.48^{\mathrm{a}}$ \\
\hline leaf index* & $2.64 \pm 0.06^{\mathrm{abc}}$ & $2.58 \pm 0.05^{\mathrm{bcd}}$ & $2.93 \pm 0.07^{\mathrm{a}}$ & $2.78 \pm 0.06^{\mathrm{ab}}$ & $2.77 \pm 0.03^{\mathrm{ab}}$ & $2.49 \pm 0.05^{\mathrm{cd}}$ & $2.66 \pm 0.05^{\mathrm{abc}}$ & $2.37 \pm 0.04^{\mathrm{d}}$ \\
\hline angle of leaf base $\left(^{\circ}\right)$ & $50.41 \pm 1.32^{\mathrm{c}}$ & $56.81 \pm 1.51^{\mathrm{b}}$ & $56.04 \pm 1.52^{\mathrm{b}}$ & $54.52 \pm 1.22^{\mathrm{bc}}$ & $51.06 \pm 0.58^{\mathrm{bc}}$ & $54.18 \pm 1.12^{\mathrm{bc}}$ & $55.10 \pm 1.02^{\mathrm{bc}}$ & $62.89 \pm 1.66^{\mathrm{a}}$ \\
\hline thickness $(\mu \mathrm{m})$ & $315.05 \pm 11.30^{\mathrm{a}}$ & $20.85 \pm 17.40^{b c}$ & $228.33 \pm 5.55^{\mathrm{cd}}$ & $297.88 \pm 16.78^{a b}$ & $243.00 \pm 12.10^{\mathrm{cd}}$ & $270.90 \pm 11.35^{\mathrm{abc}}$ & $191.43 \pm 8.90^{\mathrm{de}}$ & $173.00 \pm 7.90^{\mathrm{e}}$ \\
\hline
\end{tabular}

Columns marked by different letters differ significantly according to the Tukey's HSD test $(\mathrm{p}<0.05)$.

*: Tsukaya (2002b)

Table 3. Anatomical measurements (average \pm standard error) of epidermal cell in Eurya japonica

\begin{tabular}{|c|c|c|c|c|c|c|c|c|}
\hline & \multicolumn{6}{|c|}{ Riverside } & \multicolumn{2}{|l|}{ Inland (control) } \\
\hline & Oboke & Motoyama & Koi & Tokawa & Yusuhara & Naka & Shigeto & Noichi \\
\hline \multicolumn{9}{|c|}{ adaxial surface } \\
\hline length $(\mu \mathrm{m})$ & $20.51 \pm 0.15^{\mathrm{a}}$ & $20.37 \pm 0.18^{\mathrm{a}}$ & $20.65 \pm 0.19^{\mathrm{a}}$ & $20.36 \pm 0.46^{\mathrm{a}}$ & $20.02 \pm 0.22^{\mathrm{a}}$ & $19.92 \pm 0.16^{\mathrm{a}}$ & $20.13 \pm 0.27^{\mathrm{a}}$ & $19.93 \pm 0.25^{\mathrm{a}}$ \\
\hline width $(\mu \mathrm{m})$ & $20.60 \pm 0.11^{\mathrm{a}}$ & $20.62 \pm 0.19^{\mathrm{a}}$ & $20.94 \pm 0.20^{\mathrm{a}}$ & $20.41 \pm 0.47^{\mathrm{a}}$ & $20.22 \pm 0.22^{\mathrm{a}}$ & $20.23 \pm 0.15^{\mathrm{a}}$ & $19.91 \pm 0.20^{\mathrm{a}}$ & $20.03 \pm 0.32^{\mathrm{a}}$ \\
\hline $\operatorname{size}\left(\mu \mathrm{m}^{2}\right)$ & $401.69 \pm 7.76^{\mathrm{a}}$ & $423.77 \pm 7.73^{\mathrm{a}}$ & $436.06 \pm 8.32^{\mathrm{a}}$ & $432.15 \pm 18.61^{\mathrm{a}}$ & $406.93 \pm 9.10^{\mathrm{a}}$ & $404.48 \pm 6.26^{\mathrm{a}}$ & $401.69 \pm 7.76^{\mathrm{a}}$ & $411.94 \pm 9.59^{\mathrm{a}}$ \\
\hline \multicolumn{9}{|c|}{ abaxial surface } \\
\hline length $(\mu \mathrm{m})$ & $18.86 \pm 0.18^{\mathrm{a}}$ & $19.24 \pm 0.14^{\mathrm{a}}$ & $19.20 \pm 0.07^{\mathrm{a}}$ & $19.42 \pm 0.11^{\mathrm{a}}$ & $19.69 \pm 0.14^{\mathrm{a}}$ & $19.34 \pm 0.07^{\mathrm{a}}$ & $19.70 \pm 0.66^{\mathrm{a}}$ & $19.85 \pm 0.22^{\mathrm{a}}$ \\
\hline width $(\mu \mathrm{m})$ & $17.48 \pm 0.14^{\mathrm{ab}}$ & $17.19 \pm 0.14^{\mathrm{bc}}$ & $17.25 \pm 0.09^{\mathrm{b}}$ & $17.68 \pm 0.11^{\mathrm{ab}}$ & $17.94 \pm 0.12^{\mathrm{a}}$ & $18.05 \pm 0.11^{\mathrm{a}}$ & $18.01 \pm 0.22^{\mathrm{a}}$ & $17.99 \pm 0.22^{\mathrm{a}}$ \\
\hline $\operatorname{size}\left(\mu \mathrm{m}^{2}\right)$ & $332.33 \pm 3.52^{\mathrm{c}}$ & $332.78 \pm 4.52^{\mathrm{bc}}$ & $333.25 \pm 2.57^{\mathrm{bc}}$ & $344.90 \pm 3.83^{\mathrm{abc}}$ & $354.76 \pm 4.52^{\mathrm{ab}}$ & $349.78 \pm 2.47^{\mathrm{abc}}$ & $354.63 \pm 12.45^{\mathrm{ab}}$ & $356.44 \pm 3.66^{\mathrm{a}}$ \\
\hline
\end{tabular}

Columns marked by different letters differ significantly according to the Tukey's HSD test $(p<0.05)$.

Table 4. Anatomical measurements (average \pm standard error) of mesophyll tissues using longitudinal section in Eurya japonica

\begin{tabular}{|c|c|c|c|c|c|c|c|c|}
\hline & \multicolumn{6}{|c|}{ Riverside } & \multicolumn{2}{|c|}{ Inland (control) } \\
\hline & Oboke & Motoyama & Koi & Tokawa & Yusuhara & Naka & Shigeto & Noichi \\
\hline $\begin{array}{l}\text { epidermal cell at adaxial side } \\
\qquad(\mu \mathrm{m})\end{array}$ & $25.70 \pm 1.07^{\mathrm{a}}$ & $\begin{array}{c}20.80 \pm 1.22^{b c} \\
d\end{array}$ & $20.88 \pm 0.65^{\mathrm{bc}}$ & $26.33 \pm 0.65^{\mathrm{a}}$ & $24.35 \pm 0.67^{\mathrm{ab}}$ & $25.38 \pm 0.77^{\mathrm{a}}$ & $13.28 \pm 0.70^{\mathrm{e}}$ & $\begin{array}{c}17.18 \pm 0.58 \\
\mathrm{~d}\end{array}$ \\
\hline palisade tissue $(\mu \mathrm{m})$ & $\begin{array}{c}105.63 \pm 4.48 \\
\mathrm{a}\end{array}$ & $98.15 \pm 8.26^{\mathrm{a}}$ & $61.40 \pm 2.91^{\mathrm{b}}$ & $103.60 \pm 6.25^{\mathrm{a}}$ & $88.23 \pm 6.49^{\mathrm{a}}$ & $93.45 \pm 5.61^{\mathrm{a}}$ & $63.20 \pm 3.90^{\mathrm{b}}$ & $\begin{array}{c}59.88 \pm 3.36 \\
\mathrm{~b}\end{array}$ \\
\hline spongy tissue $(\mu \mathrm{m})$ & $\begin{array}{c}161.60 \pm 6.70 \\
a\end{array}$ & $\frac{124.30 \pm 8.12^{\mathrm{b}}}{\mathrm{c}}$ & $\frac{127.30 \pm 3.31^{b}}{c}$ & $\frac{147.73 \pm 9.63^{\mathrm{a}}}{\mathrm{b}}$ & $\frac{111.88 \pm 6.08^{c}}{d}$ & $\frac{130.03 \pm 5.45^{\mathrm{b}}}{\mathrm{c}}$ & $\frac{105.38 \pm 6.33^{\mathrm{cd}}}{\mathrm{e}}$ & $\begin{array}{c}82.30 \pm 5.26 \\
\mathrm{e}\end{array}$ \\
\hline $\begin{array}{l}\text { epidermal cell at abaxial side } \\
(\mu \mathrm{m})\end{array}$ & $22.13 \pm 0.81^{\mathrm{a}}$ & $17.60 \pm 0.82^{\mathrm{b}}$ & $18.75 \pm 0.66^{\mathrm{b}}$ & $20.23 \pm 0.59^{\mathrm{ab}}$ & $18.55 \pm 0.47^{\mathrm{b}}$ & $22.05 \pm 0.44^{\mathrm{a}}$ & $9.58 \pm 0.49^{\mathrm{d}}$ & $\begin{array}{c}13.65 \pm 0.34 \\
\mathrm{c}\end{array}$ \\
\hline
\end{tabular}


Table 5. Anatomical measurements (average \pm standard error) of stomata in Eurya japonica

\begin{tabular}{|c|c|c|c|c|c|c|c|c|}
\hline & \multicolumn{6}{|c|}{ Riverside } & \multicolumn{2}{|c|}{ Inland (control) } \\
\hline & Oboke & Motoyama & Koi & Tokawa & Yusuhara & Naka & Shigeto & Noichi \\
\hline length $(\mu \mathrm{m})$ & $19.05 \pm 0.19^{\mathrm{c}}$ & $20.00 \pm 0.13^{\mathrm{abc}}$ & $20.25 \pm 0.17^{\mathrm{ab}}$ & $19.99 \pm 0.17^{\mathrm{abc}}$ & $19.26 \pm 0.13^{b c}$ & $20.00 \pm 0.10^{\mathrm{abc}}$ & $20.10 \pm 0.18^{\mathrm{abc}}$ & $20.83 \pm 0.61^{\mathrm{a}}$ \\
\hline width $(\mu \mathrm{m})$ & $5.24 \pm 0.08^{\mathrm{a}}$ & $5.18 \pm 0.04^{\mathrm{a}}$ & $5.12 \pm 0.02^{\mathrm{a}}$ & $5.08 \pm 0.02^{\mathrm{a}}$ & $5.22 \pm 0.04^{\mathrm{a}}$ & $5.10 \pm 0.02^{\mathrm{a}}$ & $5.22 \pm 0.05^{\mathrm{a}}$ & $5.22 \pm 0.07^{\mathrm{a}}$ \\
\hline size $(\mu \mathrm{m} 2)$ & $100.41 \pm 2.38^{\mathrm{a}}$ & $103.61 \pm 1.09^{\mathrm{a}}$ & $103.89 \pm 1.16^{\mathrm{a}}$ & $101.56 \pm 1.04^{\mathrm{a}}$ & $100.66 \pm 1.24^{\mathrm{a}}$ & $102.15 \pm 1.06^{\mathrm{a}}$ & $104.75 \pm 1.34^{\mathrm{a}}$ & $107.02 \pm 1.93^{\mathrm{a}}$ \\
\hline 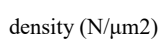 & $511.90 \pm 7.69^{\mathrm{a}}$ & $393.20 \pm 7.78^{\mathrm{b}}$ & $303.40 \pm 4.88^{\mathrm{c}}$ & $412.15 \pm 7.79^{\mathrm{b}}$ & $386.37 \pm 14.53^{\mathrm{b}}$ & $411.90 \pm 9.27^{\mathrm{b}}$ & $243.33 \pm 6.49^{\mathrm{d}}$ & $233.26 \pm 5.67^{\mathrm{d}}$ \\
\hline
\end{tabular}

We measured and calculated the mean stomatal size (guard cell area, based on guard cell pair length and width) and density using SUMP samples from the riverside and inland areas for E. japonica from all the localities we examined (Table 5). The stomatal length, width, and size of riverside populations were not significantly different from those of the inland populations. However, the stomatal density of the riverside populations was significantly higher than those of the inland populations.

\section{Discussion}

Our results indicated that Eurya japonica had morphological and anatomical differentiation of leaves under the selective pressure of rivers, similar to other previously reported rheophytes, suggesting that strong selection pressures such as a high frequency of flooding affect the leaf form in these riversides. Many plants have shown that the change in habitat from inland to riversides has been accompanied by stenophyllization; therefore, riverside plants have been distinguished as being different species and having different ecotypes (Imaichi \& Kato, 1993; Usukura et al., 1994; Tsukaya, 2002a; Ueda et al., 2012; Ohga et al., 2012). However, our results revealed that the riverside population of E. japonica did not experience stenophyllization events based on the leaf index (Table 2), although plants that grew sympatrically, such as Rhododendron ripense, Viola mandshurica var. ikedaeana, Aster microcephalus var. ripensis, and Adenophora triphylla var. japonica had narrow leaves. Our results suggest that the riverside population of $E$. japonica was not seem to be adapted along the river, but its leaf length and width were smaller along all the riversides we studied. Therefore, our results concluded that the morphological differentiation from inland to riverside populations of E. japonica was not stenophyllization but the miniaturization of leaves. However, it is doubtful whether the miniaturization of leaves played an important role in avoiding the stress caused by the river flow during flooding, even though this species had smaller leaves in all riverside populations. One of the answers was that both, stenophyllization and the miniaturization of leaves lead to a reduction in leaf width. Therefore, we considered that the reduction of leaf width was the key to morphological change to adapt along the river, regardless of whether this occurred by stenophyllization or miniaturization of leaves. To the best of our knowledge, this is the first report of rheophytic adaptation by the miniaturization of leaves.

Our anatomical results indicated that rheophytic adaptation by miniaturization of leaves in this species had experienced a decrease in the number of leaf cells because there was no significant difference in leaf cell size between riverside and inland populations (Table 3). This anatomical differentiation of the rheophytic E. japonica was similar to that of $R$. indicum f. otakumi, R. ripense, and V. mandshurica var. ikedaeana (Setoguchi \& Kajimura, 2004; Ueda et al., 2012; Matsui et al., 2013), although Dendranthema yoshinaganthum, As. microcephalus var. ripensis and Ad. triphylla var. japonica have adapted along the river by forming narrow lanceolate or cuneate leaves with not only the number of cells but also the cell size (Tsukaya, 2002a; Yamada et al., 2011). Eurya. japonica had a closer phylogenetic relationship with species belonging to Ericaceae than those of Asteraceae and Campanulaceae, and occupied a more ancestral position than the latter families (Chase et al., 1993; Soltis et al., 2000; Savolainen \& Chase, 2003; Soltis \& Soltis, 2004). These results suggest that the rheophytic modification of leaves resulted in a decreased number of cells in all angiosperms, but rheophytic leaves in the most advanced lineage were formed by changing not only the number of cells but also the cell size based on the angiosperm phylogeny (Chase et al., 1993; Soltis et al., 2000; Savolainen \& Chase, 2003; Soltis \& Soltis, 2004).

Leaves are the major organs for photosynthesis; light-demanding plants can survive and grow only under high light, and the plant can modify its morphology, anatomy, and physiological characteristics because adapting to different light environments is an important factor in increasing net carbon gain (Augspurger, 1984; Kitajima, 1994; Aleric \& Kirkman, 2005). Our morphological and anatomical results indicated that leaves of rheophytic E. japonica were thicker than those of inland populations (Table 2), and leaf thickness varied to adapt to fluctuating light conditions by changing the cell size in the adaxial-abaxial direction (Talbert \& Holch, 1957; Yano \& Terashima, 2001; Gotoh et al., 2018). In our study, all survey areas along the river were located in a large gap in the riparian forest because each river was relatively wide, and there was an environment in which a lot of sunlight radiated onto this species, suggesting that such growing environments for riverside populations of E. japonica contributed to the thickening of the leaves. Previous studies have reported that the 
rheophytic $R$. ripense, V. mandshurica var. ikedaeana, and Farfugium japonicum var. luchuence had thicker leaves than those of closely related dryland species of $R$. macrosepalum, V. mandshurica, and F. japonicum, respectively (Nomura, Setoguchi, \& Takaso, 2006; Ueda et al. 2012; Matsui et al. 2013). Therefore, the thick leaves induced along rivers were the general tendency in rheophyte plants because this modification was common to different plant lineages. From the anatomical point of view of the leaves, moreover, our results showed that the increase in leaf thickness of riverside populations of E. japonica was associated with elongation of epidermal cells, palisade tissue, and spongy tissue in the dorsoventral direction (Table 4). Li et al. (2014) reported that the intensity of light affected the thickness of cell size in a leaf, and recent morphological and physiological studies using the model plant Arabidopsis thaliana indicated that the intensity of light was involved in the thickness of the leaves, contributing to the elongation of palisade tissues in the dorsoventral axis of leaves (Hoshino et al., 2019). Therefore, our results suggest that the morphological and anatomical differentiation of leaves in the riverside populations of $E$. japonica reflected the unique light conditions along each river. In the future, it will be necessary to clarify the relationship between the amount and/or the intensity of light and the thickness of the leaves of rheophytic E. japonica.

Stomata play an important role in the regulation of gas exchange by leaves. Stomatal conductance of water vapor and CO2 is determined primarily by the size and density of stomata for a species in a certain environment, and some studies have reported that stomatal size and density are controlled by both, genetic and environmental factors (Lake, Woodward, \& Quick, 2002; Hetherington \& Woodward, 2003; Casson \& Gray, 2008; Yan, Sun, Song, \& Liu, 2012; Zhang et al., 2012). Our results indicated that the stomatal density of riverside populations was significantly higher than that of the inland populations (Table 5). The increase in stomatal density was not, however, a specific differentiation, and some similar cases have been reported in rheophytic adaptation of various angiosperms (Nomura et al., 2006; Ueda et al., 2012; Matsui et al., 2013). Some studies have indicated that changes in stomatal density in response to soil moisture appears to correspond to environmental conditions (Bakker, 1991; Miyazawa, Livingston, \& Turpin, 2006; Xu \& Zhou, 2008; Sun, Yan, Cui, \& Liu, 2014), and several approaches to improve water-use efficiency through the modification of stomatal traits have been tested in model plants (Büssis, von Groll, Fisahn, \& Altmann, 2006; Liu, Ohashi-Ito, \& Bergmann, 2009; Dow, Berry, \& Bergmann, 2014; Dittberner et al., 2018). Soils along the riversides have been reported to have a higher moisture content (Collison \& Anderson, 1996; Andreassian, 2004), suggesting that the stomatal density in the riverside population of $E$. japonica must vary under such environmental conditions.

Whether some morphological modifications in the riverside populations of E. japonica were genotypically adapted to specific environmental conditions or this was a result of phenotypic plasticity, was unclear. In general, species may be constrained by the selective pressures acting in their particular native climate, and thus a species exposed to more environmental variation in their distribution range has more phenotypic plasticity than species exposed to restricted environmental variation (Valladares, Gianoli, \& Gómez, 2007; Valladares et al. 2014). It has been reported that E. japonica grows not only along riverside but also in special environments such as coastal and serpentine areas (Itow, Hotta, \& Kawasato, 1974; Yamanaka, 1974). The fact that E. japonica grew in these special environments, even though many plants could not easily invade these areas because of their severe selection pressure, is considered to be possible because of the plasticity of this plant. Therefore, we hypothesized that E. japonica had the greatest capacity for acclimation as a result of increased phenotypic plasticity. To verify this hypothesis, artificial transplanting of E. japonica seeds between inland and riverside areas and seedling analyses would be the most obvious way to determine if it has genetic differentiation or phenotypic plasticity.

\section{Acknowledgments}

We wish to thank Drs. Ohga K (Kochi University), Kumekawa Y (Ehime University), Hayakawa H (Museum of Natural and Environmental History, Shizuoka), Yokoyama J (Yamagata University) and Yoshizaki S (Tokyo City University) for providing much help. This study was partly supported by the River Fund in charge of the Foundation of River and Watershed Environment Management (FOREM), Japan and a Grant-in-Aid for Scientific Research from the Ministry of Education, Science and Culture of Japan.

\section{References}

Aleric, K. M., \& Kirkman, L. K. (2005). Growth and photosynthetic responses of the federally endangered shrub, Linder amelissifolia (Lauraceae), to varied light environments. American Journal of Botany, 92, 682-689. https://doi.org/10.3732/ajb.92.4.682

Andreassian, V. (2004). Waters and forest: from historical controversy to scientific debate. Journal of Hydrology, 291, 1-27. https://doi.org/10.1016/j.jhydrol.2003.12.015

Augspurger, C. K. (1984). Light requirements of neotropical tree seedlings: a comparative study of growth and survival. Journal of Ecology, 72, 777-795. https://doi.org/10.2307/2259531 
Azami, K., Saitou, H., Kodama, N., \& Watanabe, M. (2001). Vegetation changes in the downstream floodplains of Miharu Dam along the Ohtakine river in Fukushima Prefecture, northeast Japan. Vegetation Science, 18, 1-12. https://doi.org/10.15031/vegsci.18.1

Bakker, J. C. (1991). Effects of humidity on stomatal density and its relation to leaf conductance. Scientia Horticulturae, 48, 205-212. https://doi.org/10.1016/0304-4238(91)90128-L

Büssis, D., von Groll, U., Fisahn, J., \& Altmann, T. (2006). Stomatal aperture can compensate altered stomatal density in Arabidopsis thaliana at growth light conditions. Functional Plant Biology, 33, 1037-1043. https://doi.org/10.1071/FP06078

Casson, S., \& Gray, J. E. (2008). Influence of environmental factors on stomatal development. New Phytologist, $178,9-23$. https://doi.org/10.1111/j.1469-8137.2007.02351.X

Chase, M. W., Soltis, D. E., Olmstead, R. G., Morgan, D., Les, D. H., Mishler, B. D., ... Albert, V. A. (1993). Phylogenetics of seed plants: an analysis of nucleotide sequences from the plastid gene rbcL. Annals of the Missouri Botanical Garden, 80, 528-580. https://doi.org/10.2307/2399846

Collison, A. J. C., \& Anderson, M. G. (1996). Using a combined slope hydrology and stability model to identify suitable conditions for landslide prevention by vegetation cover in the humid tropics. Earth Surface Processes and Landforms, 21, 737-747. https://doi.org/10.1002/(SICI)1096-9837(199608)21:8<737::AID-ESP674>3.0.CO;2-F

Dittberner, H., Korte, A., Mettler-Altmann, T., Weber, A. P. M., Monroe, G., \& de Meaux, J. (2018). Natural variation in stomata size contributes to the local adaptation of water-use efficiency in Arabidopsis thaliana. Molecular Ecology, 27, 4052-4065. https://doi.org/10.1111/mec.14838

Dow, G. J., Berry, J. A., \& Bergmann, D. C. (2014). The physiological importance of developmental mechanisms that enforce proper stomatal spacing in Arabidopsis thaliana. New Phytologist, 201, 1205-1217. https://doi.org/10.1111/nph.12586

Fujimaki, R., Kashiwagi, Y., Kubo, M., \& Yamashita, T. (2015). Chemical characteristics of soil water at a riparian forest in Mt. Sentsu, Shimane. Bulletin of Faculty of Life and Environmental Science, Shimane University, 20, 9-13. (In Japanese)

Gotoh, E., Suetsugu, N., Higa, T., Matsushita, T., Tsukaya, H., \& Wada, M. (2018). Palisade cell shape affects the light-induced chloroplast movements and leaf photosynthesis. Scientific Reports, 8, 1472. https://doi.org/10.1038/s41598-018-19896-9

Hetherington, A. M., \& Woodward, F. I. (2003). The role of stomata in sensing and driving environmental change. Nature, 424, 901-908. https://doi.org/10.1038/nature01843

Hoshino, R., Yoshida, Y., \& Tsukaya, H. (2019). Multiple steps of leaf thickening during sun-leaf formation in Arabidopsis. Plant Journal, 100, 738-753. https://doi.org/10.1111/tpj.14467

Imaichi, R., \& Kato, M. (1992). Comparative leaf development of Osmunda lancea and O. japonica (Osmundaceae): heterochronic origin of rheophytic stenophylly. Botanical Magazine Tokyo, 105, 199-213. https://doi.org/10.1007/BF02489415

Imaichi, R., \& Kato, M. (1993). Comparative leaf morphology of young sporophytes of rheophytic Osmunda lancea and dryland O. japonica. Journal of Plant Research, 106, 37-45. https://doi.org/10.1007/BF02344371

Ito, H., Ito, S., Nakao, T., \& Kadomoto, K. (2008). Effects of fluvial and geomorphic disturbances on forest dynamics of a sedimentation-dominated riparian forest in warm-temperate mountainous region in southern Japan. Japanese Society of Forest Environment, 50, 17-24. (In Japanese with English summary)

Itow, S., Hotta, H., \& Kawasato, H. (1974). Phytosociological studies on forest vegetation in western Kyushu, Japan. III. Coastal scrub communities. Bulletin of Faculty of Liberal Arts, Nagasaki University, Natural science, 15, 75-81. (in Japanese)

Kijima, M. (1962). Laboratory Manual of Botany. Hirokawa Publishing Corporation, Tokyo. (in Japanese)

Kitajima, K. (1994). Relative importance of photosynthetic traits and allocation patterns as correlates of seedling shade tolerance of 13 tropical trees. Oecologia, 98, 419-428. https://doi.org/10.1007/BF00324232

Lake, J. A., Woodward, F. I., \& Quick, W. P. (2002). Long-distance $\mathrm{CO}_{2}$ signalling in plants. Journal of Experimental Botany, 53, 183-193. https://doi.org/10.1093/jexbot/53.367.183

Li, T., Heuvelink, E., Dueck, T. A., Janse, J., Gort, G., \& Marcelis, L. F. M. (2014). Enhancement of crop photosynthesis by diffuse light: quantifying the contributing factors. Annals of Botany, 114, 145-156. 
https://doi.org/10.1093/aob/mcu071

Liu, T., Ohashi-Ito, K., \& Bergmann, D. C. (2009). Orthologs of Arabidopsis thaliana stomatal bHLH genes and regulation of stomatal development in grasses. Development, 136, 2265-2276. https://doi.org/10.1242/dev.032938

Matsui, R., Takei, S., Ohga, K., Hayakawa, H., Yoshida, M., Yokoyama, J., ... Fukuda, T. (2013). Morphological and Anatomical Variations in Rheophytic Ecotype of Violet, Viola mandshurica var. ikedaeana (Violaceae). American Journal of Plant Sciences, 4, 859-865. http://dx.doi.org/10.4236/ajps.2013.44106

Miyazawa, S. I., Livingston, N. J., \& Turpin, D. H. (2006). Stomatal development in new leaves is related to the stomatal conductance of mature leaves in poplar (Populus trichocarpa $\times$ P. deltoides). Journal of Experimental Botany, 57, 373-380. https://doi.org/10.1093/jxb/eri278

Nomura, N., Setoguchi, H., \& Takaso, T. (2006). Functional consequences of stenophylly for leaf productivity: comparison of the anatomy and physiology of a rheophyte, Farfugium japonicum var. luchuence, and a related non-rheophyte, F. japonicum (Asteraceae). Journal of Plant Research, 119, 645-656. https://doi.org/10.1007/s10265-006-0024-5

Ohga, K., Muroi, M., Hayakawa, H., Ito, K., Yokoyama, J., Tebayashi, S., ... Fukuda, T. (2012). Comparative morphology and anatomy of non-rheophytic and rheophytic types of Adenophora triphylla var. japonica (Campanulaceae). American Journal of Plant Sciences, 3, 805-809. http://dx.doi.org/10.4236/ajps.2012.36097

Saito, M., Hoshino, Y., Yoshikawa, M., \& Hoshino, J. (2019). Ecological distributions o rheophytic communities in Iriomote Island indicated by the relation between cross-sectional area of flow and catchment area. Vegetation Science, 36, 17-31. (in Japanese with English summary) https://doi.org/10.15031/vegsci.36.17

Savolainen, V., \& Chase, M. W. (2003). A decade of progress in plant molecular phylogenetics. Trends in Genetics, 19, 717-724. https://doi.org/10.1016/j.tig.2003.10.003

Setoguchi, H., \& Kajimura, G. (2004). Leaf morphology of the rheophyte, Rhododendron indicum f. otakumi (Ericaceae). Acta Phytotaxonomica et Geobotanica, 55, 45-54. https://doi.org/10.18942/apg.KJ00004622803

Shimada, H., \& Tani, H. (2005). Characteristics of Satoyama forests in Mie Prefecture. Bulletin of the Mie Prefecture Forestry Research Institute, 17, 19-44. (in Japanese)

Soltis, D. E., Soltis, P. S., Chase, M. W., Mort, M. E., Albach, D. C., Zanis, M., ... Farris, J. S. (2000). Angiosperm phylogeny inferred from a combined data set of $18 \mathrm{~S}$ rDNA, $r b c L$ and atpB sequences. Botanical Journal of Linnean Society, 133, 381-461. https://doi.org/10.1006/boj1.2000.0380

Soltis, P. S., \& Soltis, D. E. (2004). The origin and diversification of angiosperms. Americal Journal of Botany, 91, 1614-1626. https://doi.org/10.3732/ajb.91.10.1614

Sun, Y., Yan, F., Cui, X., \& Liu, F. (2014). Plasticity in stomatal size and density of potato leaves under different irrigation and phosphorus regimes. Journal of Plant Physiology, 171, 1248-1255. https://doi.org/10.1016/j.jplph.2014.06.002

Talbert, C. M., \& Holch, A. E. (1957). A study of the lobing of sun and shade leaves. Ecology, 38, 655-658. https://doi.org/10.2307/1943135

Tsukaya, H. (2002a). Leaf anatomy of a rheophyte, Dendranthema yoshinaganthum (Asteraceae), and of hybrids between D. yoshinaganthum and a closely related non-rheophyte, D. indicum. Journal of Plant Research, 115, 329-333. https://doi.org/10.1007/s10265-002-0041-y

Tsukaya, H. (2002b). The leaf index: heteroblasty, natural variation, and the genetic control of polar process of leaf expansion. Plant Cell Phisiology, 43, 372-378.

Ueda, R., Minamiya, Y., Hirata, A., Hayakawa, H., Muramatsu, Y., Saito, M., \& Fukuda, T. (2012). Morphological and anatomical analyses of rheophytic Rhododendron ripense Makino (Ericaceae). Plant Species Biology, 27, $223-240$. https://doi.org/10.1111/j.1442-1984.2011.00345.x

Usukura, M., Imaichi, R., \& Kato, M. (1994). Leaf morphology of a facultative rheophyte, Farfugium japonicum var. luchuense (Compositae). Journal of Plant Research, 107, 263-267. https://doi.org/10.1007/BF02344253

van Steenis, C. G. G. J. (1981). Rheophytes of the world. Sijthoff and Noordhoff, Alpen aan den Rijn.

Valladares, F., Gianoli, E., \& Gómez, J. M. (2007). Ecological limits to plant phenotypic plasticity. New Phytologist, 176, 749-763.

Valladares, F., Matesanz, S., Guilhaumon, F., Araújo, M. B., Balaguer, L., Benito-Garzón, M., ... Zavala, M. A. (2014). The effects of phenotypic plasticity and local adaptation on forecasts of species range shifts under climate change. Ecology Letters, 17, 1351-1364. https://doi.org/10.1111/ele.12348 
Xu, Z., \& Zhou, G. (2008). Responses of leaf stomatal density to water status and its relationship with photosynthesis in a grass. Journal of Experimental Botany, 59, 3317-3325. https://doi.org/10.1093/jxb/ern185

Yamada, Y., Hayakawa, H., Minamiya, Y., Ito, K., Shibayama, Z., Arakawa, R., \& Fukuda, T. (2011). Comparative morphology and anatomy of rheophytic Aster microcephalus (Miq.) Franch. et Sav. var. ripensis Makino (Asteraceae). Journal of Phytogeography and Taxonomy, 59, 35-42. http://doi.org/10.24517/00053453

Yamaguchi, M. (2004). Tree planting for biotope. Environmental Conservation Engineering, 33, 880-884. (in Japanese)

Yamanaka, T. (1974). Sociological studies on the serpentine vegetation, XVII: Supplementary notes on the serpentine vegetation at low altitudes in Shikoku. Bulletin of Faculty of Education, Kochi University, 23, 21-35. (in Japanese)

Yan, F., Sun, Y., Song, F., \& Liu, F. (2012). Differential responses of stomatal morphology to partial root-zone drying and deficit irrigation in potato leaves under varied nitrogen rates. Scientia Horticulturae, 145, $76-83$. https://doi.org/10.1016/j.scienta.2012.07.026

Yano, S., \& Terashima, I. (2001). Separate localization of light signal perception for sun or shade type chloroplast and palisade tissue differentiation in Chenopodium album. Plant Cell and Physiology, 42, 1303-1310. https://doi.org/10.1093/pcp/pce183

Zhang, L., Niu, H., Wang, S., Zhu, X., Luo, C., Li, Y., \& Zhao, X. (2012). Gene or environment? Species specific control of stomatal density and length. Ecology and Evolution, 2, 1065-1070. https://doi.org/10.1002/ece3.233

\section{Copyrights}

Copyright for this article is retained by the author(s), with first publication rights granted to the journal.

This is an open-access article distributed under the terms and conditions of the Creative Commons Attribution license (http://creativecommons.org/licenses/by/4.0/). 